\title{
Population structure and regeneration of Himalayan endemic Larix species in three high-altitude valleys in Nepal Himalaya
}

\author{
Man Kumar Dhamala ${ }^{1 *} \mathbb{D}$, Prakash Chandra Aryal ${ }^{2,3}$, Madan Krishna Suwal $^{4}$, Sijar Bhatta ${ }^{2}$ and Dinesh Raj Bhuju ${ }^{5}$
}

\begin{abstract}
Background: The Himalayan forests are of great importance to sustain the nature and community resource demands. These forests are facing pressures both from anthropogenic activities and ongoing global climatic changes. Poor natural regeneration has been considered a major problem in mountainous forests. To understand the population structure and regeneration status of Larix (Larix griffithiana and Larix himalaica), we conducted systematic vegetation surveys in three high-altitude valleys namely Ghunsa (Kanchenjunga Conservation Area, KCA), Langtang (Langtang National Park, LNP), and Tsum (Manaslu Conservation Area, MCA) in Nepal Himalaya. The average values of diameter at breast height (DBH), height, and sapling height were compared for three sites and two species using Kruskal-Wallis test. Population structure was assessed in terms of proportion of seedlings, saplings, and trees. Regeneration was analyzed using graphical representation of frequencies of seedlings, saplings, and trees in histograms.

Results: The results showed that the population structure of Larix in terms of the proportion of seedling, sapling, and tree varied greatly in the three study areas. KCA had the highest record of seedling, sapling, and tree compared to other two sites. Seedlings were the least among three forms and many plots were without seedlings. We found no seedling in MCA study plots. The plot level average DBH variation among sites was significant (Kruskal-Wallis $X^{2}=7.813, \mathrm{df}=2, p=0.02$ ) as was between species (Kruskal-Wallis $X^{2}=5.9829, \mathrm{df}=1, p=0.014$ ). Similarly, the variation in average tree height was significant (Kruskal-Wallis $x^{2}=134.23, \mathrm{df}=2, p<0.001$ ) among sites as well as between species (Kruskal-Wallis $X^{2}=128.01$, $\mathrm{df}=1, p<0.001$ ). All the sites showed reverse J-shaped curve but more pronounced for KCA and MCA. In comparing the two species, Larix griffithiana has clear reverse Jshaped diameter distribution but not Larix himalaica.

Conclusion: The varied responses of Larix manifested through regeneration status from spatially distinct areas show that regeneration limitations might be more pronounced in the future. In all the three studied valleys, regeneration of Larix is found to be problematic and specifically for Larix griffithiana in MCA and Larix himalaica in LNP. To address the issues of disturbances, especially serious in LNP, management interventions are recommended to sustain the unique Himalayan endemic conifer.
\end{abstract}

Keywords: Anthropogenic disturbance, Climate change, Endemic, Subalpine, Forest management

\footnotetext{
* Correspondence: mkdhamala@cdes.edu.np

${ }^{1}$ Central Department of Environmental Science, Tribhuvan University, Kirtipur, Kathmandu, Nepal

Full list of author information is available at the end of the article
}

(c) The Author(s). 2020 Open Access This article is licensed under a Creative Commons Attribution 4.0 International License, which permits use, sharing, adaptation, distribution and reproduction in any medium or format, as long as you give appropriate credit to the original author(s) and the source, provide a link to the Creative Commons licence, and indicate if changes were made. The images or other third party material in this article are included in the article's Creative Commons licence, unless indicated otherwise in a credit line to the material. If material is not included in the article's Creative Commons licence and your intended use is not permitted by statutory regulation or exceeds the permitted use, you will need to obtain permission directly from the copyright holder. To view a copy of this licence, visit http://creativecommons.org/licenses/by/4.0/. 


\section{Background}

The Himalayan forests are important part of nature conservation and socioecological systems sustaining mountain livelihoods. The forests investigated in the study are relatively unique types. Growing in harsh climatic conditions in Himalayan valleys, especially under slow growth environments of low temperature and moisture availability, these forests face challenges in terms of exposure to natural and anthropogenic disturbances. One of the major risks to the high-altitude tree species like Larix is availability of regeneration niche, survival from seed to seedling and sapling to the tree stage.

High-altitude forests, especially subalpine forests, in the Himalaya are prone to anthropogenic disturbances due to severe climatic conditions and high-altitude residence of local people (Miehe and Miehe 2000; Gairola et al. 2014). The common anthropogenic disturbances in these forests include grazing, fuel wood collection, logging, clear felling, extraction of timber, fodder and other non-timber forest products by the local people (Byers 1996; Carpenter and Zomer 1996; Byers 1997; Kala et al. 2002; Schickhoff 2005; Maren and Sharma 2018). Forests have traditionally been exploited in the study sites in multiple ways to maximize economic and social benefits. Recently, the socioeconomic organization in the highaltitude areas and public attitudes towards the forest and forestry have changed dramatically with the growth of tourism and other recreational activities (Nepal 2002; Stevens 2003; Sacareau 2009; Neupane et al. 2014; $\mathrm{Mu}$ et al. 2019), and the goals of forest management now extend far beyond those of the past to embrace the demand for new ecological and recreational functions (Maren and Sharma 2018; Bhutiya et al. 2019).

Fragility of the Himalayan landscapes and their susceptibility to natural hazards and concerns about current and potential climate change impacts are ongoing (Barnett et al. 2005; Tewari and Verma 2017; Roy and Rathore 2019). The concerns are also mounting on the loss of biodiversity and threats to food security (Sharma et al. 2009; Xu et al. 2009). With the increase in population pressure, natural and socioeconomic systems in the Himalaya are at threat, especially with reference to rapid globalization (Roy and Rathore 2019). A far greater impact of climate change has been predicted on already-stressed ecosystems of the study area (Sharma et al. 2009).

Understanding the structure and composition of native forests is a prerequisite in developing an adaptive forest management plan for Himalayan forest ecosystems where climate change is rapid (Bhutiya et al. 2019). Population demography is crucial to understand current species distribution patterns (Gaston 2009; Purves 2009; Bell et al. 2013) and to predict their future dynamics (Pagel and Schurr 2012; Normand et al. 2014). In fact, the population structure (age or size) of tree species is a well-known way to provide valuable information about the population dynamics (Dang et al. 2010; Dolanc et al. 2012), and regeneration is considered the determinant factor driving population dynamics at the range limits (Rickebusch et al. 2007) because the regenerating individuals of long-lived trees are most sensitive or fragile to environment variability, particularly extreme events (Castro et al. 2004).

While seed availability and successful dispersal are important precursors, germination and seedling establishment are the critical steps that determine the compatibility between the environment and the respective regeneration. The regeneration niche of trees can be expected to become constricted under the increasingly harsh conditions and the substantially different ecosystem properties in the subalpine and alpine areas. On the other hand, tree species regeneration is a rather stochastic process, difficult to model due to the high variability in space, time, and nature of the factors involved (Benavides et al. 2016).

In Nepal, trees of Larix occur in scattered stands on open soils of landslide areas but are certainly trees which climb as high as treeline ecotone (Miehe and Miehe 2000). Larix griffithiana Carriere (the Sikkim Larch) is a medium-sized deciduous, coniferous tree native to the eastern Himalaya in eastern Nepal, Sikkim, western Bhutan, and southern China. It grows between 3000 and $4100 \mathrm{~m}$ altitude. L. griffithiana forms pure stands on the depositional terraces, loose slopes, and other places prone to a higher rate of disturbance (Carpenter and Zomer 1996). L. griffithiana forests of the Kanchenjunga region are ecologically significant because they represent the western most extreme for this unique, deciduous conifer of the eastern Himalaya. L. griffithiana is fairly common from the Sikkim to South West China and Kanchenjunga supports the only extensive, pure stands found in Nepal.

Larix himalaica W. C. Cheng \& L. K. Fu (the Langtang Larch) is also a deciduous, coniferous tree native to the Himalaya growing between 3000 and $3800 \mathrm{~m}$ in the river valleys. Langtang valley is the locus classicus for the species but it is also found in the valleys on the northern side of Mount Everest (Bayton and Grimshaw 2020). In Langtang valley, L. himalaica prefers ancient moraines where it is mixed with bushy Juniperus and Rhododendron (Sakai and Malla 1981). Consequently, the Larix is an excellent species for studying impacts of climatic and anthropogenic influences on high-altitude trees/forests based on population structure and regeneration dynamics.

Larix species in montane and subalpine Himalaya represent the lowest latitude (southern end) of Larix's range (Mamet et al. 2019) and is in need of more studies in 
the context of Nepal with inadequate information on structure and regeneration. It is mainly because these species are confined to the central and eastern Himalaya, especially south and east and distribution of the species appears to have a very restricted range. Our goal in the present study was to assess the structure and regeneration of the Larix species using field data.

\section{Materials and methods}

\section{Study area}

Three valleys viz. Ghunsa (Taplejung) in Kanchenjunga Conservation Area (KCA), Tsum (Gorkha) in Manaslu Conservation Area (MCA), and Langtang (Rasuwa) in Langtang National Park (LNP) were selected for the field studies (Fig. 1).

Table 1 summarizes biophysical attributes of the three studied valleys. These are high-altitude valleys in the Himalaya, characterized by upper temperate and subalpine climatic conditions. The valleys are dominated by upper temperate and subalpine forests mainly composed of conifers like Larix species, Abies spectabilis, and some broadleaf species like Betula utilis forming treelines. These watersheds are traversed by rivers forming major branches of Koshi and Narayani river systems. The geology of these areas is dominated by moraine and alluvial, coarse and loose sediments of glacial or fluvial deposits.

General climatic conditions are severe winters and mild summer. Most of the precipitation is received as snowfall and rainfall is significantly supporting forests and agriculture practices. Economically, the people rely on agriculture and animal husbandry system and are very dependent on natural resources for firewood, timber, and medicinal plants. They are also engaged in trade and tourism related enterprises. Agricultural production is very limited due to limited agriculture land, lack of irrigation, low temperature for long periods, and low rainfall. Crops grown are chiefly potato, wheat, buckwheat, and vegetables.

As in other parts of the Himalaya, transhumance is still practiced in all the three study sites. Livestock include yak and horses and grazing is common practice throughout the areas. The cattle herds are taken to the highlands during the summer and are brought back to the lowland during the winter (Aryal et al. 2014). We observed signs such as lopping, cut stumps, grazing, trampling, and droppings. In MCA and LNP, timber harvesting was observed from the studied forest for the construction of houses, hotels, and restaurants damaged by the 2015 Gorkha Earthquake.

\section{Studied forests}

The forests investigated in the study are relatively unique types. Among the three sites, Larix griffithiana was recorded from two sites, i.e., $\mathrm{KCA}$ and MCA, and $L$. himalaica from LNP. Growing in harsh climatic conditions in Himalayan valleys, especially under slow growth environments of low temperature and moisture availability, these forests face challenges in terms of exposure to natural and anthropogenic disturbances. In all the three study sites, local people practice Tibetan Buddhism. Poles of Larix are used as stands for prayers' flag (Kunwar 2011). The wood of Larix is valued as good timber and fuelwood (Shrestha 2008).

In $\mathrm{KCA}$, the study site was a 2 -h walk from Ghunsa village. Larix griffithiana here forms pure stands on depositional terraces, loose slopes, and other places prone

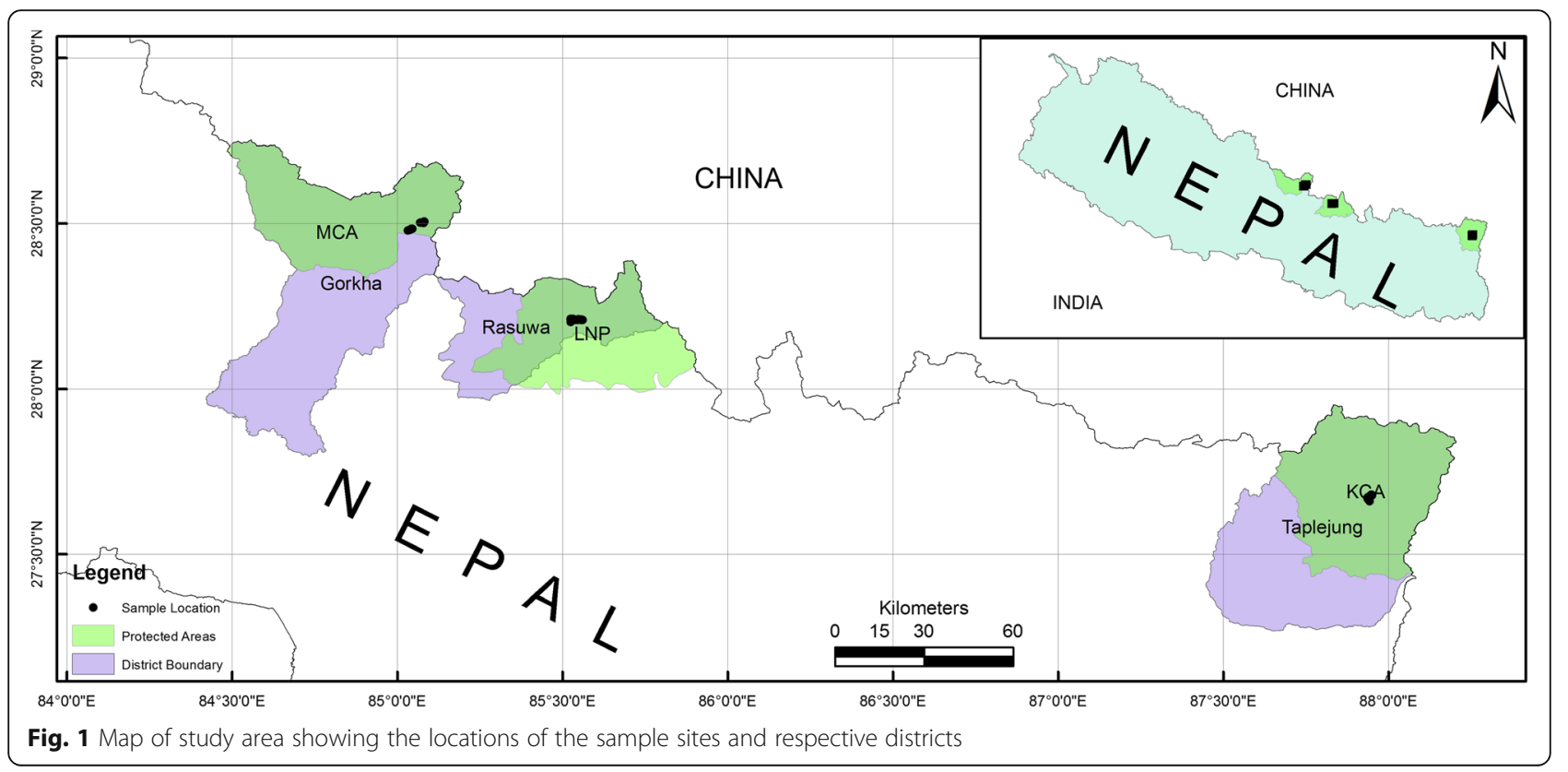


Table 1 Biophysical attributes of the three studied valleys

\begin{tabular}{|c|c|c|c|}
\hline Attributes & Kanchenjunga Conservation Area (KCA) & Manaslu Conservation Area (MCA) & Langtang National Park (LNP) \\
\hline Location name & Ghunsa valley & Tsum valley & Langtang valley (Kyangjin) \\
\hline Geographic coordinates & $27^{\circ} 39^{\prime} 38.8^{\prime \prime} \mathrm{N}, 87^{\circ} 56^{\prime} 38.4^{\prime \prime} \mathrm{E}$ & $27^{\circ} 43^{\prime} 19.9^{\prime \prime} \mathrm{N}, 85^{\circ} 21^{\prime} 52,2^{\prime \prime} \mathrm{E}$ & $28^{\circ} 12^{\prime} 6.5^{\prime \prime} \mathrm{N}, 85^{\circ} 31^{\prime} 32.1^{\prime \prime} \mathrm{E}$ \\
\hline Elevation range $(\mathrm{m})$ & $3200-3500$ & $3200-3700$ & $3300-3800$ \\
\hline Climatic regime & Subalpine & Subalpine & Subalpine \\
\hline Mean annual precipitation (mm) & 1920 & 690 & 689 \\
\hline Number of studied plots & 21 & 11 & 12 \\
\hline Major forest composition & $\begin{array}{l}\text { Larix griffithiana, Abies spectabilis, } \\
\text { Pinus wallichiana, Tsuga dumosa, } \\
\text { Betula utilis, Rhododendron species, } \\
\text { Juniperus species }\end{array}$ & $\begin{array}{l}\text { Larix griffithiana, Pinus wallichiana, } \\
\text { Abies spectabilis, Rhododendron } \\
\text { species }\end{array}$ & $\begin{array}{l}\text { Larix himalaica, Pinus } \\
\text { wallichiana, Abies spectabilis }\end{array}$ \\
\hline
\end{tabular}

to a higher rate of disturbance. It is a charismatic east Himalayan vegetation type (Chaudhary et al. 2015). The altitude of varies between 3200 and $3500 \mathrm{~m}$ above sea level (masl). The gymnosperm, Ephedra forms frequent groundcover along with species of Juniperus and Rhododendron (Carpenter et al. 1994).

In MCA, the study site was near Lamagaun, about a 2 and half-hour walk from Chhekampaar. The altitude varies between 3200 and 3700 masl. Larix griffithiana here forms small patches and is associated with Pinus wallichiana and Abies spectabilis. The ground vegetation consists of thickets of Rhododendron species. In this ancient settlement of Tsum valley, the forest is valued for wood products especially timber for the construction of houses, hotels, restaurants, and Buddhist temples.

In LNP, the study site was near Mundu about 1 and half-hour walk from the Langtang valley (Kyangjin). The altitude varies between 3300 and 3800 masl. Larix himalaica is a deciduous conifer common in northern slopes. It is a pioneer species in landslide and soil-eroded areas. $L$. himalaica can survive on the strand, beach of ice melting streams, and rivers and tolerate the low temperature and poor nutritional condition (Qiaozhi et al. 2010). L. himalaica prefers ancient moraines where it is mixed with bushy Juniperus and Rhododendron. Sometimes, it associates with Hippophae salicifolia in soil-eroded areas as a pioneer succession.

\section{Taxonomic description of Larix species}

Larix himalaica W. C. Cheng \& L. K. Fu is a deciduous, coniferous species of tree that grows to heights of $50 \mathrm{~m}$ tall with a trunk that measures $100 \mathrm{~cm}$ in diameter, measured at breast height with a conical crown. It is distinguished by longer seed cones up to $6.5 \mathrm{~cm}$ with different shaped bracts, mucronate-cuspidate. Young shoots are lighter in color at yellow-orange (Zheng-yi and Raven 1999; Farjon 2001; http://www.efloras.org/). In Nepal, the species is reported from the LNP.
Larix griffithiana Carriere is a deciduous coniferous species of tree that grows of over $20 \mathrm{~m}$ tall with trunks measuring $80 \mathrm{~cm}$ in diameter at breast height. The crown is slender conic and the main branches are level to upswept, with the side branchlets pendulous from them. Seeds cones are mature to brown or light brown in color, cylindric or cydric-ellipsoid in shape, $5-11 \mathrm{~cm}$ long and $2.2-3 \mathrm{~cm}$ wide. Shoots are diamorphic, and long shoots are red-brown, light brown, or yellow-brown in color and $10-50 \mathrm{~cm}$ long. Short shoots are $6-8 \mathrm{~mm}$ in diameter, nearly smooth, with remnants of bud scales and rings of revolute scale bases. Winter buds are ovoidglobose or globose in shape and not resinous (Zheng-yi and Raven 1999; Farjon 2001; http://www.efloras.org/). This species is native to the eastern Himalayan mountains: eastern Nepal, Sikkim, Bhutan, India's Arunachal Pradesh, and China growing at elevations of 3000-4100 $\mathrm{m}$ above sea level.

\section{Vegetation surveys}

Vegetation surveys were conducted from September 2015 to May 2016. For surveying the vegetation, we followed systematic sampling approach (Kent and Cocker 1992). We carried out vegetation surveys in all sites using 20-m wide belt transects. We laid belt transects of $200 \mathrm{~m}$ along altitude whenever possible and 100 $\mathrm{m}$ otherwise. Whenever, altitudinal belt was not possible, we laid horizontal belts across the slopes. We surveyed a total of seven transects, three in KCA, two in MCA and two in LNP. We laid alternative quadrats $(20 \mathrm{~m} \times 20 \mathrm{~m})$ in the belt transects. In total, we laid 44 quadrats from three sites that include 21, 11, and 12 quadrats from $\mathrm{KCA}, \mathrm{MCA}$, and LNP, respectively. In all the quadrats, we identified Larix trees, measured the tree height using Suunto Clinometer and diameter at breast height (DBH) of trees (at $1.30 \mathrm{~m}$ above the ground) using DBH tape. Due to steep slope, the standard procedure of measurement was not possible in some quadrats. In such cases, we measured the height employing ocular method. We 
first standardized the ocular height estimation by comparing the clinometer measurements prior to quadrat survey using tree in gentle slopes. All the field members repeatedly estimated the tree height and measured tree height to check the difference in estimation and measurements until an accuracy of $10 \pm 5 \mathrm{~cm}$ in estimated and measured height was acquired for 30 random trees selected. We included border trees in plots when more than $50 \%$ of the tree stem fell inside the quadrat and excluded otherwise. We identified and counted all the seedlings and measured the height of saplings in the sample quadrats. Along with Larix, we also recorded associated tree species but did not conduct counting and measurements. Plot level elevation, geographical position, slope, and disturbance signs were also recorded in the field.

\section{Data analysis}

Vegetation data obtained from sample plots were managed on the basis of individual trees with DBH, height, and sapling height. Regenerating individuals were clustered into two size classes based on the life stage, that is, seedling $(H<1 \mathrm{~m})$ or sapling $(H \geq 1 \mathrm{~m}$ and $\mathrm{DBH}<10$ $\mathrm{cm})$. The plot level data involving average value of $\mathrm{DBH}$, height, and sapling height were calculated averaging or totaling the individuals in the plot. The frequencies of tree size (DBH and height) and sapling height are presented in histograms with median values for the three sites and two species.

Regeneration of Larix was analyzed using graphical representation of seedling, sapling, and tree frequencies in histograms. The average values of DBH, height, sapling height, tree number, and sapling numbers were compared for three sites and two species using KruskalWallis test and represented graphically. Kruskal-Wallis test is a non-parametric test equivalent of analysis of variance (ANOVA) for continuous dependent variable and categorical predictor variable. All the analyses were carried using R (https://www.R-project.org/).

\section{Results}

\section{Population structure}

We measured a total of 463 trees from 44 plots in three sites. The population structure of tree species in terms of proportion of seedlings, saplings, and trees varied greatly in the three study areas. KCA has the highest density of seedling, sapling, and trees compared to other sites. Seedlings were the least among three forms and many plots were without seedlings. We found no seedling in MCA plots. Furthermore, the sapling density is the lowest for MCA with only 12 saplings from all the plots (Table 2, for plot level number see supplementary material).
Table 2 Density (individuals/ha) of seedling, sapling, and tree records in the three study sites

\begin{tabular}{llll}
\hline Site & Seedling & Sapling & Tree \\
\hline KCA & $0-125(120 \pm 243)$ & $0-1100(233 \pm 339)$ & $25-850(263 \pm 203)$ \\
MCA & 0 & $0-100(27 \pm 36)$ & $125-475(280 \pm 120)$ \\
LNP & $0-100(27 \pm 37)$ & $50-450(179 \pm 131)$ & $75-400(244 \pm 112)$
\end{tabular}

Data from KCA and MCA represent Larix griffithiana and from LNP represent L. himalaica

Tree height distribution among three sites showed different features. KCA and MCA had trees of (Larix griffithiana) wider height range compared to LNP (Larix himalaica). Throughout the sampling plots, smaller and fewer trees were observed in LNP compared to other two sites. The median tree heights were $11.5 \mathrm{~m}$ in $\mathrm{KCA}$, $9.5 \mathrm{~m}$ in MCA, and $6 \mathrm{~m}$ for LNP. LNP samples had most of the trees in height range of 4 to $6 \mathrm{~m}$ and none of the trees was higher than $10 \mathrm{~m}$ (Fig. 2). The median heights of trees belonging to L. griffithiana, i.e., $10 \mathrm{~m}$ is greater than the trees belonging to L. himalaica i.e. $6 \mathrm{~m}$ (Fig. 3).

Tree size in terms of DBH and height varied among sites. Combined data showed a plot level average diameter of around $21 \mathrm{~cm}$, similar for all three sites (Table 3). Average tree $\mathrm{DBH}$ among plots was higher for KCA and MCA $(21.8 \mathrm{~cm})$ compared to LNP $(18.9 \mathrm{~cm})$. The plot level average DBH varied significantly among sites (Kruskal-Wallis $\chi^{2}=7.813, \mathrm{df}=2, p=0.02$ ) and between species (Kruskal-Wallis $\chi^{2}=5.9829, \mathrm{df}=1, p=0.014$ ). However, the average tree height among three sites was more varied with $6.2 \mathrm{~m}$ in LNP and $10 \mathrm{~m}$ in KCA. The variation in average tree height was significantly different (Kruskal-Wallis $\chi^{2}=134.23$, df $=2, p<0.001$ ) with smaller stand height for LNP and significant variations between two species (Kruskal-Wallis $\chi^{2}=128.01, \mathrm{df}=1$, $p<0.001$ ).

Except the trees below $10 \mathrm{~cm}$ diameter, all the sites showed reverse J-shaped curve, more pronounced for KCA and MCA. Trees in KCA ranged up to $64 \mathrm{~cm}$ and most of the tree size is in range of $10-20 \mathrm{~cm}$ and abrupt decline beyond $10-20 \mathrm{~cm}$ DBH class. LNP had most of the trees confined in narrow size range of $10-30 \mathrm{~cm}$ compared to two other areas that have more trees beyond those size classes. The median $\mathrm{DBH}$ values were $18 \mathrm{~cm}, 20 \mathrm{~cm}$, and $17 \mathrm{~cm}$ for KCA, MCA, and LNP, respectively (Fig. 4). In comparing two species, Larix griffithiana has clear reverse J-shaped diameter distribution but not Larix himalaica. Moreover, the median DBH of L. griffithiana $(18.75 \mathrm{~cm})$ was slightly more than that of L. himalaica $(17 \mathrm{~cm})$ (Fig. 5).

\section{Regeneration status}

Large size trees were fewer in all of the three study sites and LNP in particular. Density of regenerating individuals, that is, seedlings and saplings, were very low across 

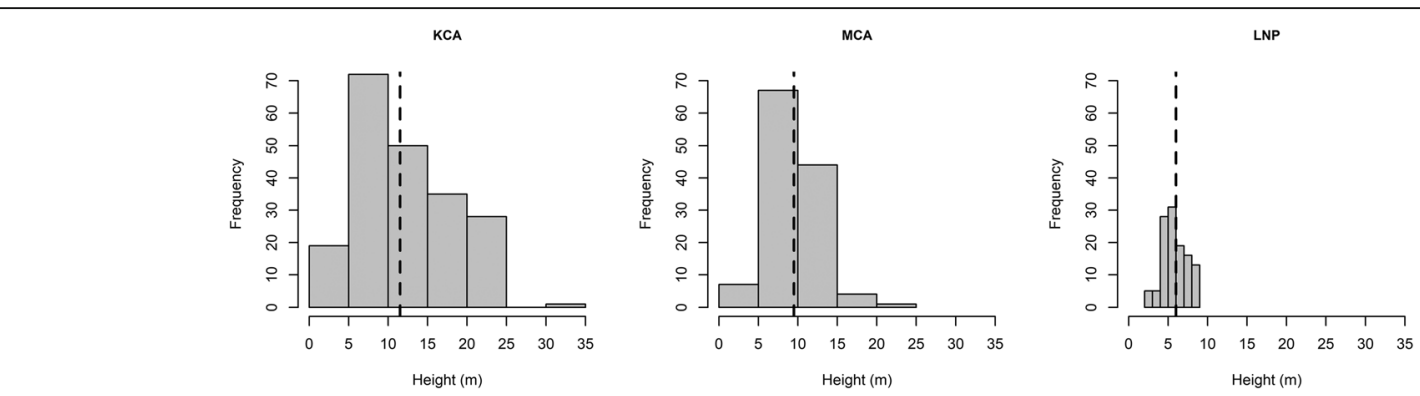

Fig. 2 Frequency distribution of tree height in three sites. The vertical dashed lines represent the median values

the three sites. More saplings were recorded from KCA compared to other sites and LNP had more saplings than MCA (Table 2, for plot level number please see supplementary material). It is also evident that all the sites have dominance of same sapling height classes between 2 and $4 \mathrm{~m}$ and exceptionally tall saplings were recorded in KCA (Fig. 6). Average sapling height was lower in LNP $(2.9 \mathrm{~m})$ compared to KCA $(4.3 \mathrm{~m})$ and MCA (3.9 m) (Table 3) with significant variations (Kruskal-Wallis $\chi^{2}=28.75$, $\mathrm{df}=2, p<0.001$ ). In comparing the two species, the median sapling height of Larix griffithiana was greater than the median sapling height of Larix himalaica (Fig. 7) with significant variation (Kruskal-Wallis $\chi^{2}=28.69, \mathrm{df}=1, p<0.001$ ).

\section{Discussion}

In Nepal, forest represents $44.47 \%$ of the total land area of the country (DFRS 2015). More than $80 \%$ of people heavily depend on agriculture and livestock rearing for subsistence (Maren et al. 2015). High-altitude forests in Nepal provide different essential services (e.g., firewood, construction materials, edible and medicinal plants) which are integral to the subsistence survival in demanding environmental conditions. Understanding forest characteristics including regeneration is, therefore, fundamentally important for efficient management of forests.

Various anthropogenic and ecological factors determine the forest structure and composition (Dolezal and Srutek 2002). We constructed diameter size distribution diagram to assess the population structure and regeneration of trees as it is widely used for the purpose (Leak 1964; Weat et al. 1981). Our results showed that except for Larix himalaica in LNP, the tree recruitment and regeneration for long term (based on tree size distribution) is expected to be sustainable with respect to the presence of growing number of trees of Larix griffithiana in KCA and MCA. Our results are similar with the findings in old-growth conifer forests in Bhutan (Moktan 2010). J-shaped curve for DBH distribution is expected because collected data is only for Larix species rather than whole communities and reverse J-shaped distributions are typical of both balanced, uneven-aged stands and even-aged stratified mixed species stands. These types of irregularly shaped curves are characteristics of irregular, unevenaged stands.

For all of the three sites, the DBH size distribution is not bell shaped as these curves are characteristic of

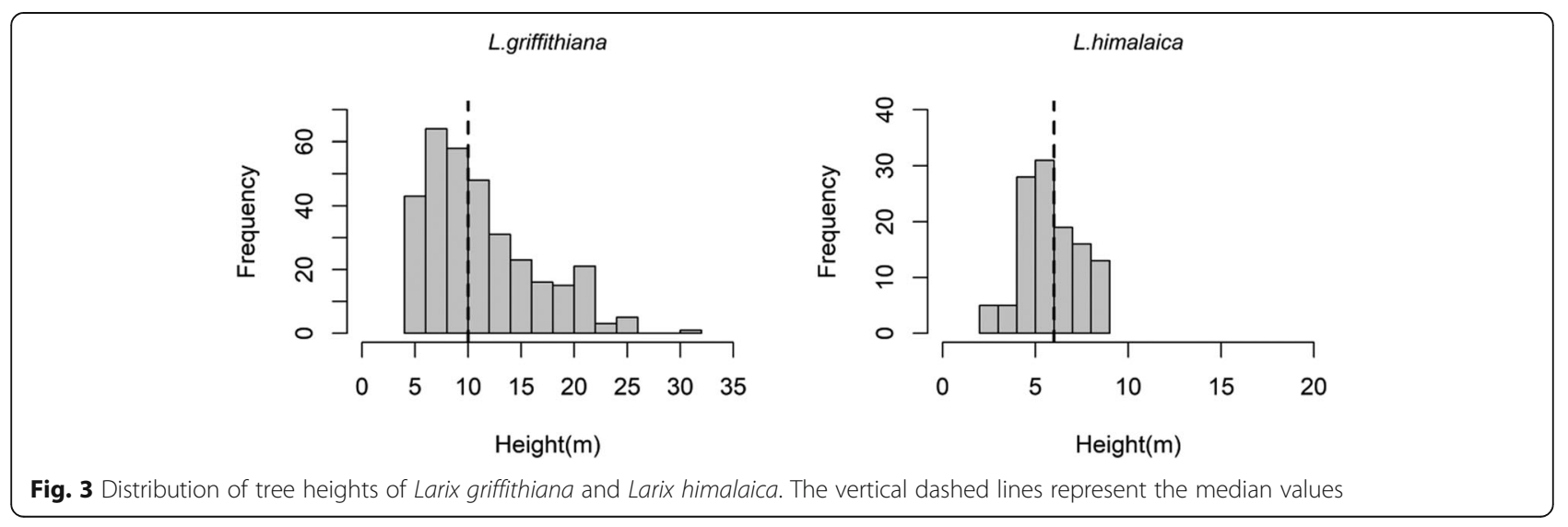


Table 3 Descriptive statistics for tree (DBH and height) and sapling (height) size distribution

\begin{tabular}{lllll}
\hline Parameter & Overall & KCA & MCA & LNP \\
\hline DBH $(\mathrm{cm})$ & $10-64(21.1 \pm 9.6)$ & $10-64(21.8 \pm 10.9)$ & $10-53(21.89 \pm 8.9)$ & $10-40.7(18.9 \pm 7.28)$ \\
Height $(\mathrm{m})$ & $2.5-32(10.0 \pm 5.1)$ & $4-32(12.4 \pm 5.8)$ & $4.3-25(9.7 \pm 3.3)$ & $2.5-9(6.03 \pm 1.52)$ \\
Sapling height $(\mathrm{m})$ & $1-10.5(3.8 \pm 2.02)$ & $1.2-10.5(4.3 \pm 1.8)$ & $1.5-7(3.9 \pm 1.7)$ & $1-6(2.9 \pm 1.2)$ \\
\hline
\end{tabular}

"Overall" represents combined data from all three sites and other columns are for site-specific measures. The statistics are presented in minimum-maximum (mean \pm standard deviation) format

single-species even-aged stands (Camp 1999); that is not the case for Himalayan natural forest, though they are anthropogenically controlled. Further, tree age distribution determines stand size structure and is related to disturbance history and stand dynamics (Bondarev 1997). However, lack of large size trees across the study sites and for both species is a scenario undesirable for a sustainable forest management. Our findings could be the result from low to moderate severity disturbances that generated stands composed of multiple age and irregular size classes. Commonly, irregular, uneven-aged stands show irregularly shaped curves (Camp 1999). Moreover, the size range of trees in LNP should be taken as matter of concern as both $\mathrm{DBH}$ and height measurements were in narrow range compared to other two sites. Narrow band of tree height sizes and the coppiced trees in LNP show past anthropogenic disturbances.

The presence of seedlings and sapling numbers compared to tree number are fundamental to understand species-wise regeneration status. The sapling limitations and low stature of sapling need careful attention and especially Larix griffithiana in MCA and Larix himalaica in LNP. This is because adequate numbers of regenerating plants, i.e., seedlings and saplings, are essential for regeneration and inadequate numbers are indicative of poor regeneration quality (Ali et al. 2019). An analysis of vegetation in temperate forest in Lachung Range of the Sikkim Himalaya recorded the minimum adult density of L. griffithiana and Populus jacquemontiana (Subba et al. 2015). In temperate and subalpine forests of Nepal, spatially heterogeneous distribution of seedlings and saplings was observed in other tree species such as Quercus semecarpifolia in LNP (Vetaas 2000), Betula utilis in Manang (Shrestha et al. 2007) and LNP (Kunwar 2011), and Abies spectabilis in MCA and Gaurishankar Conservation Area (Suwal et al. 2016). The small population of L. himalaica in LNP deserves further investigations considering the influence of natural or anthropogenic factors and management interventions.

The regeneration of the plant is the key ecological process in a forest ecosystem in which seeding and sprouting of woody species are involved (Pratt et al. 2012). One of the most important problems that mountainous forests are experiencing is poor regeneration (Karauchi et al. 2000), which is especially observed in subalpine forests in Eastern Himalaya (Tambe et al. 2011; Pandey et al. 2018) as well as in Western Himalaya (Rai et al. 2012). Poor regeneration and naturally slow growing nature of Larix griffithiana are documented in subalpine forests in Sikkim Himalaya (Tambe et al. 2011) and absence of seedlings and saplings of the species has been recorded in temperate forests in Lachung Range of the Sikkim Himalaya (Subba et al. 2015). Similarly, fewer number (29.1\%) of younger age classes individuals of Larix potaninii was reported in some studied plots in Tibet (Cui et al. 2017). Previous research from MCA in Nepal documented non-uniform distribution of saplings and seedlings with absence of seedlings and saplings in $60 \%$ and $25 \%$ of the sampling plots, respectively, both being completely absent from higher elevation (3800-4000 m) (Sujakhu et al. 2013).

Various ecological (natural) and anthropogenic factors determine the regeneration and or recruitment of a
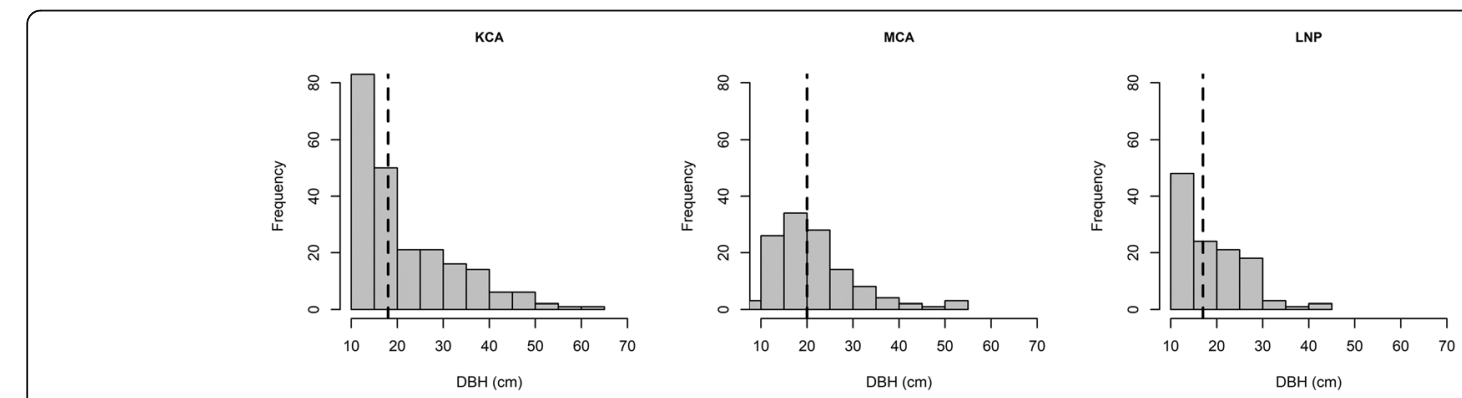

Fig. 4 Frequency distribution of Larix tree DBH in three study sites. The vertical dashed lines represent the median values 
L.griffithiana

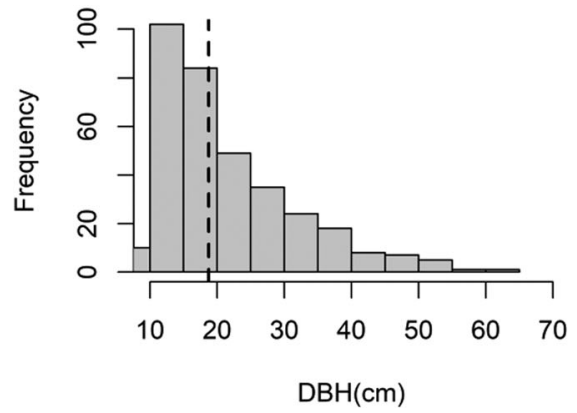

L.himalaica

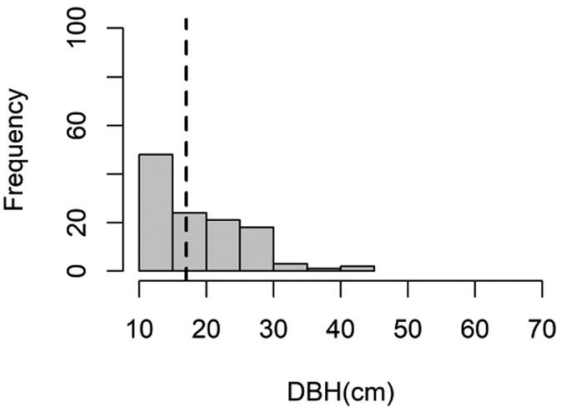

Fig. 5 DBH distributions of Larix griffithiana and Larix himalaica. The vertical dashed lines represent median values

species (Vetaas 2000; Kala et al. 2002; Castro et al. 2004; Dolanc et al. 2012; Benavides et al. 2016,). In Nepal, trees of Larix occur in scattered stands on open soils of landslide areas (Miehe and Miehe 2000), on the depositional terraces, loose slopes, and other places prone to a higher rate of disturbance (Carpenter and Zomer 1996) including ancient moraines (Sakai and Malla 1981). The microclimate controlled by slope-climate-moisture interactions have found to cause profound impact on tree recruitment of Larix potaninii in alpine treeline ecotone in the eastern margin of the Tibetan Plateau, China (Cui et al. 2017). Similarly, tree regeneration and community structure of $L$. potaninii was found to be influenced by the understory bamboo Fargesia denudata in the Wang Lang Natural Reserve, Sichuan, China (Taylor et al. 1996). In the Lvliang Mountains of central China, natural regeneration of Larix principis-rupprechtii was found to be challenging and influenced by litter thickness, parent trees, slope, and soil nutrients (Liang and Wei 2020). These factors, i.e., slope, moisture, climate, understory vegetation, litter thickness and soil nutrients, might hold relevance in regeneration of Larix species in the study sites. However, in order to fully understand the regeneration dynamics of the species in Nepal Himalaya, a comprehensive study identifying the key factors influencing the regeneration is essential.

The disturbance regime might hold more sense while assessing the regeneration of Larix as all the sites in the present study were under human use for timber and fuel wood collection and cattle grazing. In LNP, disturbance was reported to be increased along altitude up to treeline complementing regeneration of unpalatable species and detrimental for susceptible tree such as Larix himalaica (Kunwar 2011). In western Bhutan Himalayas, number of regenerating individuals of Larix griffithiana were reported fewer in disturbed (logged) forest stands than in undisturbed (unlogged) stands (Moktan et al. 2009). In our findings, variations in number of seedling and sapling among sites varied significantly showing different regeneration regimes. Absence of seedlings in MCA sample sites indicates a regeneration gap owing to disturbances. This further indicates that the replacement in tree size classes from sapling stage is not proportional and the population may decline in the long-term as regeneration is considered one of the most vital processes in the replacement of old trees with young ones (Singh et al. 2016).
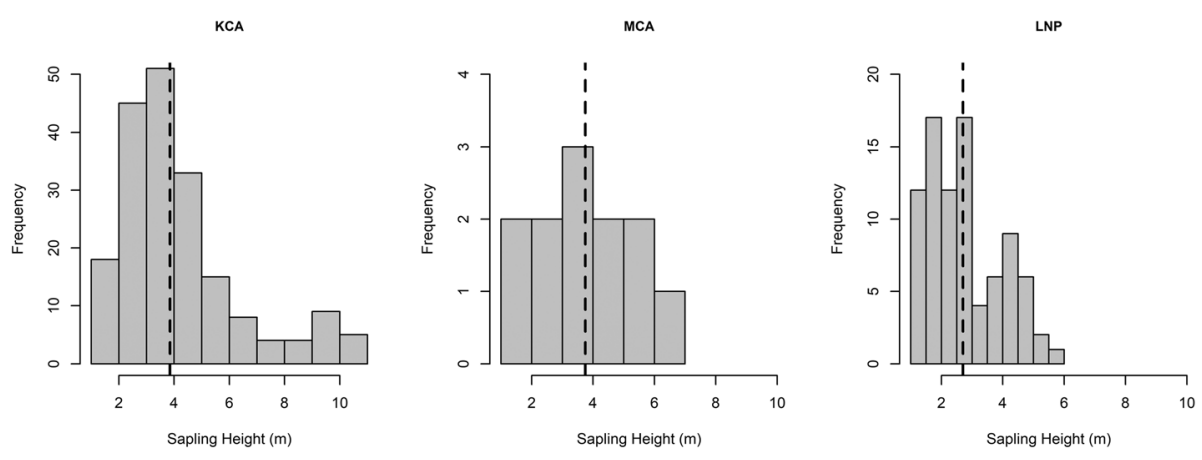

Fig. 6 Frequency distribution of sapling height in three sites. The vertical dashed lines represent the median values 
L.griffithiana

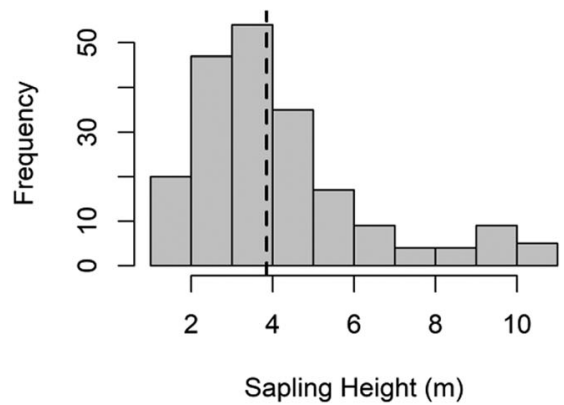

L.himalaica

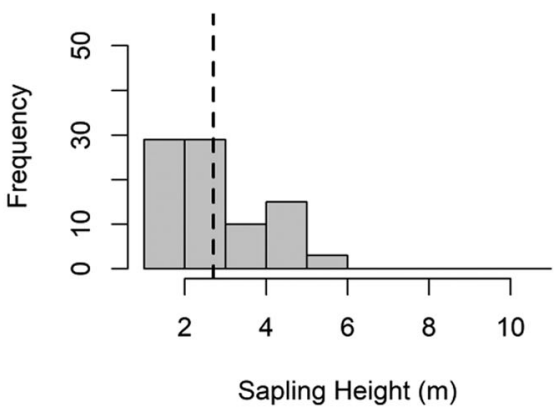

Fig. 7 Frequency distribution of sapling height of Larix griffithiana and Larix himalaica. The vertical dashed lines represent the median values

Climate plays a critical role in successful growth of trees in high altitude areas (Daniels and Veblen 2003; Piermattei et al. 2012). Changing recruitment rate of subalpine tree populations could indicate the effects of climate change (Wong et al. 2010). Climate change is expected to directly alter the composition of communities and the functioning of ecosystems across the globe (Mokany et al. 2015). Recent studies (Bhatta et al. 2018; Aryal et al. 2020) have already shown the influence of climate on growth of Larix species in Nepal Himalaya. Phenophase adjustments such as flower initiation of Larix himalaica was noted in LNP (Kunwar 2011). Moreover, small patchiness of Larix forests in the Himalaya with restricted distributional range and persistent anthropogenic disturbance make them more vulnerable to the impacts of climate change as smaller forest patches always have relatively weaker resilience under the same climatic conditions (Peters 1990; Xu et al. 2017). Therefore, further improved understanding of relationship between these high altitude forests and climate and its variations under the influence of rapid global change is a major priority to help identify management responses that will retain diverse, functioning ecosystems as well as the livelihoods of people who depend on these resources.

Our findings confirmed the lack of regenerating individuals of Larix across the three high-altitude valleys in Nepal Himalaya. Sustainability of populations with inadequate number or lack of regenerating individuals has been reported to be challenging for several species of subalpine trees. Examples include Larix potaninii in China (Taylor et al. 1996; Cui et al. 2017; Liang and Wei 2020), Larix griffithiana in Sikkim, India (Tambe et al. 2011; Subba et al. 2015), and Bhutan (Moktan 2010); and for many other species in the eastern Himalaya (Pandey et al. 2018), Nepal Himalaya (Vetaas 2000; Shrestha et al. 2007; Kunwar 2011; Sujakhu et al. 2013; Maren et al. 2015; Suwal et al. 2016), and western
Himalaya (Rai et al. 2012). Therefore, for the effective conservation of the typical Himalayan vegetation of Larix forests, efforts need to be concentrated both locally and regionally. Knowledge base of the traditional grazing patterns of yak and sheep herds will be essential in devising management interventions. For the sustainability of Larix forests, prohibition of herding activities along with regulation in harvesting of poles and trees are considered important. Across the Himalaya wood of Larix is valued as good fuelwood (Kunwar 2011); therefore, providing alternatives to firewood use is a key in sustainability of the Larix forests. Promotion of solar heaters and ensuring access to alternate and cheap forms of energy and fuel-efficient devices will help in substantially reducing the pressure on these forests. Further, tourism is expected to grow in all the three sites and since post-earthquake reconstruction work is still underway in LNP and MCA, the importance of integrating biodiversity conservation with socio-economic development is needed to be explored.

\section{Conclusion}

Larix forests in the study sites consist of irregular, uneven-aged stands with irregularly shaped DBH distribution and could be due to low to moderate anthropogenic disturbances in the past. Although high-altitude areas experience slow rate of vegetation development and regeneration, the regeneration of Larix in all the three high-altitude valleys is found rather problematic and especially Larix himalaica in LNP. The regeneration limitations occur due to survival problems of young plants because largely of anthropogenic disturbances coupled with climatic stress. Due to limitation in regeneration, the smaller population of Larix himalaica in LNP may experience severe impacts from anthropogenic disturbances. Similarly, the absence of seedlings and low number of saplings of Larix griffithiana in sampled plots of MCA indicate that the area may experience 
population declines in the near future. Moreover, absence of large size trees across the study sites and for both species is a scenario undesirable for a sustainable forest. On the other hand, these small patches of Himalayan endemic Larix species are more vulnerable to ongoing global climate change necessitating careful and immediate planning and management strategies.

\section{Supplementary information}

Supplementary information accompanies this paper at https://doi.org/10 1186/s41610-020-00166-7.

Additional file 1. Table: Number of tree, sapling and seedling records in plots from three sites. Data from KCA and MCA represent Larix griffithiana and from LNP represent L. himalaica.

\section{Abbreviations}

DBH: Diameter at breast height; KCA: Kanchenjunga Conservation Area; LNP: Langtang National Park; MCA: Manaslu Conservation Area

\section{Acknowledgements}

This paper is based on research financed under the Climate Change Research Grants Program implemented by the Nepal Academy of Science and Technology. The Program is part of the Mainstreaming Climate Change Risk Management in Development project. This project is a component of Nepal's Pilot Program for Climate Resilience and is executed by the Ministry of Population and Environment (Nepal), financed by the Climate Investment Funds, administered by the Asian Development Bank with technical assistance from ICEM, METCON, and APTEC. We also would like to thank the Department of National Park and Wildlife Conservation (DNPWC) and all the three protected areas for granting us permission for field studies. Thanks are also due to Mr. Nabin Kishor Bimali and Mr. Bhumiswar Sharma for their help in the field.

\section{Authors' contributions}

MKD, PCA, and MKS conceptualized the research. MKD and PCA designed methodology. MKD, PCA, and SB collected data. PCA curated data. PCA and MKS analyzed the data. MKD and PCA wrote original draft manuscript. MKD, PCA, SB, MKS, and DRB reviewed and edited the manuscript. All authors have read and agreed to the published version of the manuscript.

\section{Funding}

The research is funded by the Climate Change Research Grants Program implemented by the Nepal Academy of Science and Technology. The funder had no role in the design of the study; in the collection, analyses, or interpretation of data; in the writing of the manuscript; or in the decision to publish the results.

\section{Availability of data and materials}

All data involved in this study are available upon request.

Ethics approval and consent to participate

Not applicable.

\section{Consent for publication}

Not applicable.

\section{Competing interests}

All the authors declare that they have no competing interests.

\section{Author details}

${ }^{1}$ Central Department of Environmental Science, Tribhuvan University, Kirtipur, Kathmandu, Nepal. ${ }^{2}$ Environmental Science Program, GoldenGate International College, Battisputali, Kathmandu, Nepal. ${ }^{3}$ Environment Protection and Study Center (ENPROSC), Baneshwor, Kathmandu, Nepal. ${ }^{4}$ Department of Geography, University of Bergen, Bergen, Norway. ${ }^{5} \mathrm{Nepal}$ Academy of Science and Technology, Khumaltar, Lalitpur, Nepal.
Received: 1 July 2020 Accepted: 10 September 2020

Published online: 24 September 2020

\section{References}

Ali A, Dai D, Akhtar K, Teng MJ, Yan ZG, Urbina-Cardona N, et al. Response of understory vegetation, tree regeneration, and soil quality to manipulated stand density in a Pinus massoniana plantation. Glob Ecol Conserv. 2019;20: e00775.

Aryal PC, Dhamala MK, Gaire NP, Bhatta S, Suwal MK, Bhuju DR, et al. Tree-ring climate response of two Larix species from the Central Nepal Himalaya. Trop Ecol. 2020;61:215-25.

Aryal S, Maraseni TN, Cockfield G. Sustainability of transhumance grazing systems under socio-economic threats in Langtang, Nepal. J Mt Sci-Eng. 2014;11: 1023-34.

Barnett TP, Adam JC, Lettenmaier DP. Potential impacts of a warming climate on water availability in snow-dominated regions. Nature. 2005;438:303-9.

Bayton R, Grimshaw J. Trees and shrubs onlinehttp://treesandshrubsonline.org/ articles/larix/larix-himalaica/. Accessed 07 September; 2020.

Bell DM, Bradford JB, Lauenroth WK. Mountain landscapes offer few opportunities for high-elevation tree species migration. Glob Chang Biol. 2013;20(5):1441-51.

Benavides R, Escudero A, Coll L, Ferrandis P, Ogaya R, Gouriveau F, et al. Recruitment patterns of four tree species along elevation gradients in Mediterranean mountains: not only climate matters. For Ecol Manag. 2016; 360:284-96.

Bhatta S, Dhamala MK, Aryal PC, Chauhan R, Dawadi B. Climate variability and associated response of Larix griffithii in Kanchenjunga conservation area of Nepal. Appl Ecol Environ Sci. 2018;6(1):23-30.

Bhutiya Y, Gudasalamani R, Ganesan R, Saha S. Assessing forest structure and composition along the altitudinal gradient in the state of Sikkim, eastern Himalaya, India. Forests. 2019;10(8):633.

Bondarev A. Age distribution patterns in open boreal Dahurican larch forests of Central Siberia. For Ecol Manag. 1997:93(3):205-14.

Byers AC. Historical and contemporary human disturbance in the upper Barun valley, Makalu-Barun National Park and conservation area. Mt Res Dev. 1996; 16(5):235-47

Byers AC. Landscape change in Sagarmatha (Mt. Everest) National Park, Khumbu, Nepal. Himalaya. 1997;17(2):16.

Camp AE. Age structure and species composition changes resulting from altered disturbance regimes on the eastern slopes of the cascades range, Washington. J Sustainable For. 1999:9:39-67.

Carpenter C, Ghimire S, Brown T. Report on the flora and fauna of Kanchenjunga region. Kathmandu: WWF Nepal; 1994.

Carpenter C, Zomer R. Forest ecology of the Makalu-Barun National Park and conservation area, Nepal. Mt Res Dev. 1996;16(2):135-48.

Castro J, Zamora R, Godar JA, Gomez JM. Seedling establishment of a boreal tree species (Pinus sylvestris) as its southernmost distribution limit: consequences of being in a marginal Mediterranean habitat. J Ecol. 2004;92:266-77.

Chaudhary RP, Uprety Y, Joshi SP, Shrestha KK, Basnet KB, Basnet G, et al. Kangchenjunga landscape Nepal: from conservation and development perspectives. Kathmandu: Ministry of Forests and Soil Conservation (MoFSC), Government of Nepal; Research Centre for Applied Science and Technology (RECAST), Tribhuvan University; and International Centre for Integrated Mountain Development (ICIMOD); 2015.

Cui J, Qin J, Sun H. Population spatial dynamics of Larix potaninii in alpine treeline ecotone in the eastern margin of the Tibetan plateau, China. Forests. 2017:8(10):356.

Dang $\mathrm{H}$, Zhang $\mathrm{Y}$, Zhang $\mathrm{K}$, Jiang $\mathrm{M}$, Zhang $\mathrm{Q}$. Age structure and regeneration of subalpine fir (Abis fargesii) forests across an altitudinal range in the Qinling Mountains, China. For Ecol Manag. 2010:259(3):547-54.

Daniels LD, Veblen TT. Altitudinal treelines of the southern Andes near $40^{\circ} \mathrm{S}$. For Chron. 2003;79(2):237-41.

DFRS. State of Nepal's forests. Kathmandu: Department of Forest Research and Survey, Ministry of Forests and Soil Conservation; 2015.

Dolanc CR, Thorne JH, Safford HD. Widespread shifts in the demographic structure of subalpine forests in the sierra Navada, California, 1934-2007. Glob Ecol Biogeogr. 2012;22(3):264-76.

Dolezal J, Srutek M. Altitudinal changes in composition and structure of mountain temperate vegetation: a case study from the western Carpathians. Plant Ecol. 2002;158:201-21. 
Farjon A. World checklist and biogeography of conifers. Kew: The Royal Botanical Gardens; 2001

Gairola S, Rawal RS, Todaria NP, Bhatt A. Population structure and regeneration patterns of tree species in climate-sensitive subalpine forests of Indian Western Himalaya. J For Res. 2014;25:343-9.

Gaston KJ. Geographic range limits of species. Proc R Soc B. 2009;276:1391-3.

Kala CP, Singh SK, Rawat GS. Effects of sheep and goat grazing on the species diversity in the alpine meadows of Western Himalaya. Environmentalist. 2002; 22:189-202.

Karauchi N, Brang P, Schonenberger W. Forests of mountainous regions: gaps in knowledge and research needs. For Ecol Manag. 2000;132(1):73-82.

Kent M, Cocker P. Vegetation description and analysis: a practical approach. New York: John Wiley and Sons; 1992.

Kunwar RM. Assessment of climate change impacts on non timber forest products (NTFPs), medicinal and aromatic plants (MAPs) and important tree species (ITS) in the sacred Himalayan landscape, Nepal. Kathmandu: WWF Nepal Program; 2011.

Leak WB. An expression of diameter distribution for unbalanced, uneven-aged stands and forests. For Sci. 1964;10:39-50.

Liang W, Wei X. Factors promoting the natural regeneration of Larix principisrupprechtii plantation in the Lvliang Mountains of Central China. PeerJ. 2020; 8:e9339.

Mamet SD, Brown CD, Trant AJ, Laroque CP. Shifting global Larix distributions: northern expansion and southern retraction as species respond to changing climate. J Biogeogr. 2019;46:30-44.

Maren IE, Karki S, Prajapati C, Yadav RK, Shrestha BB. Facing north or south: does slope aspect impact forest stand characteristics and soil properties in a semiarid trans-Himalayan valley? J Arid Environ. 2015;121:112-23.

Maren IE, Sharma LN. Managing biodiversity: impacts of legal protection in mountain forests of the Himalayas. Forests. 2018;9:476.

Miehe G, Miehe S. Comparative high mountain research on the treeline ecotone under human impact. Erdkunde. 2000;54(1):34-50.

Mokany K, Thomson JJ, Lynch AJJ, Jordan GJ, Ferrier S. Linking changes in community composition and function under climate change. Ecol Appl. 2015;25(8):2132-41.

Moktan MR. Impacts of recent policy changes on rural communities and species diversity in government-managed forests of Western Bhutan. Mt Res Dev. 2010;30(4):365-72.

Moktan MR, Gratzer G, Richards WH, Rai TB, Dukpa D, Tenzin K. Regeneration of mixed conifer forests under group tree selection harvest management in western Bhutan Himalayas. For Ecol Manag. 2009;257:2121-32.

Mu Y, Nepal SK, Lai P. Tourism and sacred landscape in Sagarmatha (Mt. Everest) National Park, Nepal. Tour Geogr. 2019;21(3):442-59.

Nepal SK. Tourism as a key to sustainable mountain development: the Nepal Himalaya in retrospect. Unasylva. 2002;53:38-45.

Neupane GP, Lew AP, Tatsugawa K. Perceptions of trekking tourism and social and environmental change in Nepal's Himalayas. Tour Geogr. 2014; 16(3):415-37.

Normand S, Zimmermann NE, Schurr FM, Lischke H. Demography as the basis for understanding and predicting range dynamics. Ecography. 2014;37(2):1149-54.

Pagel J, Schurr FM. Forecasting species ranges by statistical estimation of ecological niches and spatial population dynamics. Glob Ecol Biogeogr. 2012; 21:293-304.

Pandey A, Badola HK, Rai S, Singh SP. Timberline structure and woody taxa regeneration towards treeline along latitudinal gradients in Khangchendzonga National Park, eastern Himalaya. PLoS One. 2018;13(11): e0207762.

Peters RL. Effects of global warming on forests. For Ecol Manag. 1990;35:13-33.

Piermattei A, Renzaglia F, Urbinati C. Recent expansion of Pinus nigra Arn. Above the timberline in the central Apennines, Italy. Ann For Sci. 2012;69:509-17.

Pratt RB, Jacobsen AL, Hernandez J, Ewers FW, North GB, Davis SD. Allocation tradeoffs among chaparral shrub seedlings with different live story types (Rhamnaceae). Am J Bot. 2012;99(9):1464-76.

Purves DW. The demography of range boundaries versus range cores in eastern US tree species. Proc R Soc B. 2009;276:1477-84.

Qiaozhi M, Makoto W, Takayoshi K. Growth characteristics of two promising tree species for afforestation, birch and larch in the northern part of Asia. Eurasian J Forest Res. 2010;13(2):69-76.

Rai ID, Adhikari BS, Rawat GS, Bargali K. Community structure along timberline ecotone in relation to micro-topography and disturbances in Western Himalaya. Notulae Sci Biol. 2012;4(2):41-52.
Rickebusch S, Lischke H, Bugmann H, Guisan A, Zimmermann NE. Understanding the low-temperature limitations to forest growth through calibration of a forest dynamics model with tree-ring data. For Ecol Manag. 2007;246(2-3): 251-63.

Roy A, Rathore P. Western Himalayan forests in climate change scenario. In: Navalgund R, Kumar A, Nandy S, editors. Remote sensing of northwest Himalayan ecosystems. Singapore: Springer; 2019. p. 265-86.

Sacareau I. Changes in environmental policy and mountain tourism in Nepal. J Alpine Res (Online). 2009;97(3):1-11.

Sakai A, Malla SB. Winter hardiness of tree species at high altitudes in the east Himalaya, Nepal. Ecology. 1981;61(5):1288-98.

Schickhoff $U$. The upper treeline in the Himalayas, Hindu Kush and Karakorum: a review of geographical and ecological aspects. In Broll G, Keplin B. mountain ecosystems. Heidelberg: Springer; 2005.

Sharma E, Chhetri N, Tse-ring K, Shrestha AB, Jing F, Mool P, et al. Climate change impacts and vulnerability in the eastern Himalayas Kathmandu: ICIMOD; 2009.

Shrestha BB, Ghimire B, Lekhak HD, Jha PK. Regeneration of treeline birch (Betula utilis D. Don) forest in a trans-Himalayan dry valley in Central Nepal. Mt Res Dev. 2007;27(3):259-67.

Shrestha UT. Adaptation to climate change in water management, agro-biodiversity and forestry with species reference to Nepal. Initiation. 2008;2:113-20.

Singh S, Malik ZA, Sharma CM. Tree species richness, diversity, and regeneration status in different oak (Quercus spp.) dominated forests of Garhwal Himalaya, India. J Asia-Pac Biodivers. 2016;9:293-300.

Stevens S. Tourism and deforestation in the Mt. Everest region of Nepal. Geogr J. 2003;169(3):255-77.

Subba S, Lachunga S, Subba S, Nepal S. Analysis of vegetation in a representative temperate plant community in Lachung range of the Sikkim Himalaya. NeBIO. 2015;6(3):18-24.

Sujakhu H, Gosai KR, Karmacharya SB. Forest structure and regeneration pattern of Betula utilis D. Don in Manaslu conservation area, Nepal. ECOPRINT. 2013; 20:107-13.

Suwal MK, Shrestha KB, Guragain L, Shakya R, Shrestha K, Bhuju DR, et al. Land-use change under a warming climate facilitated unslope expansion of Himalayan silver fir (Abies spectabilis (D. Don) Spach). Plant Ecol. 2016;217(8):993-1002.

Tambe S, Arrawatia ML, Sharma N. Assessing the priorities for sustainable forest management in the Sikkim Himalaya, India: a remote sensing based approach. J Indian Soc Remote Sens. 2011;39:555-64.

Taylor AH, Zisheng Q, Jie L. Structure and dynamics of subalpine forests in the Wang Lang natural reserve, Sichuan, China. Vegetatio. 1996;124:25-38.

Tewari VP, Verma RK. Gadow Kv. Climate change effects in the Western Himalayan ecosystems of India: evidence and strategies. For Ecosyst. 2017;4(13):1-9.

Vetaas OR. The effect of environmental factors on the regeneration of Quercus semecarpifolia Sm. In central Himalaya, Nepal. Plant Ecol. 2000;146:137-44.

Weat DC, Shugart HH, Ranney JW. Population structure of forests over a large area. For Sci. 1981;27:701-10.

Wong MH, Duan C, Long Y, Luo Y, Xie G. How will the distribution and size of subalpine Abies georgei forest respond to climate change? A study in Northwest Yunnan, China. Phys Geogr. 2010;31(4):319-35.

Xu C, Liu H, Anenkhonov OA, Korolyuk AY, Sandanov DV, Balsanova LD, et al. Long-term effect resilience to climate change indicated by mortality, regeneration, and growth in semiarid southern Siberia. Glob Chang Biol. 2017;23(6):2370-82.

Xu J, Grumbine RE, Shrestha A, Eriksson M, Yang X, Wang Y, et al. The melting Himalayas: cascading effects of climate change on water, biodiversity and livelihoods. Conserv Biol. 2009;23:520-30.

Zheng-yi W, Raven PH. Editors. Flora of China, volume 4. Beijing and St. Louis: Science Press and Missouri Botanical Garden; 1999.

\section{Publisher's Note}

Springer Nature remains neutral with regard to jurisdictional claims in published maps and institutional affiliations. 